\title{
新しく馬に認められた $\mathrm{Hb}$ 型の一例
}

\author{
横浜道成・茂木一重・細田達雄
}

競走馬理化学研究所

One Example of Hemoglobin Type Observed newly in Horse Mi chinari Yokohama, Kazushige Mogi and Tatsuo Hosoda Laboratory of Racing Chemistry, Tokyo 158

馬のへモグロビン型 ( $\mathrm{H}$ b型) はBraend \& Stormont ( $\left.\begin{array}{llll}1 & 9 & 6 & 4\end{array}\right)$, Schleger \&

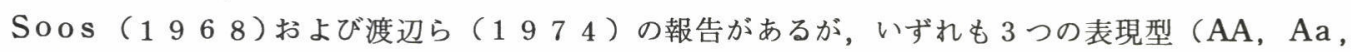
a a ）であるとしている。遺伝的には一対の優劣関係にある対立遺层子により支配されていると報告 している。すなわち， H b 型の泳動像は 2 つの成分よりなり易動度の遅いバンドに変異が認めら机, $\mathrm{Hb} \mathrm{A}$ バンドを有するものとこれを欠くものによって分類されている。

本報告は上記の分類法に該当しない一例が北海道和種に認められたので報告する。

\section{材料および方法}

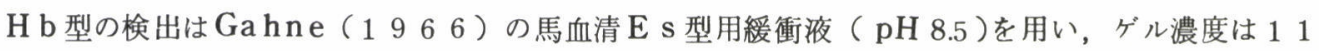
$\%$ にして泳動は冷室において約 $4 \mathrm{~mA} / \mathrm{cm}$ の定電流で 2 時間行なった。 $\mathrm{H} \mathrm{b}$ サンプルは 63 頭の北海道 和種（ 2 才以上）より採取したものである。

\section{結果および考察}
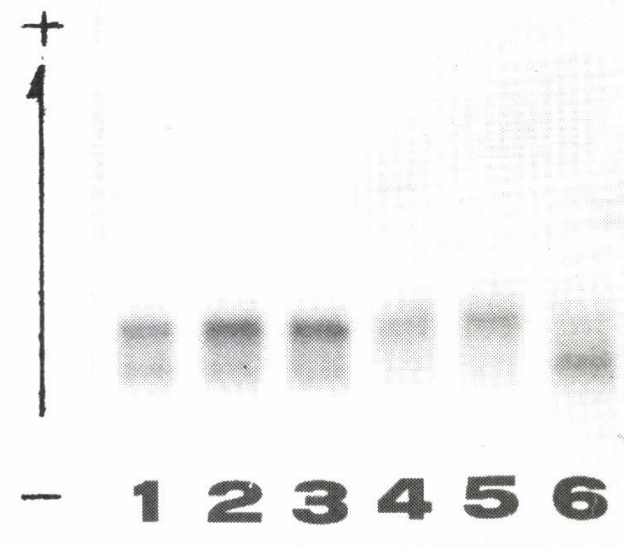

Fig. 1. Electrophoretogram of hemoglobin type in Hokkaido-native horse

1: AA type, 2-3: Aa type, 4-5: aa type, 6: $X$ type 
図 1 は H b 型の泳動パターンを示してある。No. 1 は A A 型, No. 2 と 3 は A a 型およびNa. 4 と 5 は a a 型である。これらの 3 つの表現型は $\mathrm{Br}$ a e nd らによってこれまで報告された易動度の遅い $\mathrm{Hb}$ Aバンドの変異により分離されたものである。一方, No.6のパターンは易動度の速いバンドの変異で ある（表 1 におけるX)。この個体は 5 才の雌馬であるが，この変異が遺伝的なものか，または病的 要因等による一時的変化であるのかは残念ながらその後の追跡調査が不可能であったため明らかにす ることはできなかった。

このような $\mathrm{H} \mathrm{b}$ 型の報告がすでになされているか否かについては確認することはできなかったが，

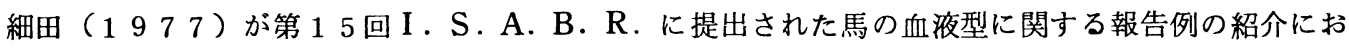
いては, 南アのOsterhoff が馬の $\mathrm{Hb}$ 型を $\mathrm{A}_{1}, \mathrm{~A}_{1} \mathrm{~A}_{2}, \mathrm{~A}_{1}^{+} \mathrm{A}_{2}^{-}$および $\mathrm{A}_{1}^{-} \mathrm{A}_{2}^{+}$の 4 型に表現型 を分類している。今回認められたNNa.6 個体のタイプがこれらの 4 型のうちに該当するものがあるか否 かは明らかでないが，No. 6 個体の H b 型が一時的变化でないとすれば Os t e r hof f の分類も興味が もたれる。

なお， 63 頭の $\mathrm{H} \mathrm{b}$ 型の出型頻度は表 1 に示した如くで，AA型が $69.8 \% ， \mathrm{~A} \mathrm{a}$ 型が $25.4 \% ， \mathrm{a} a$ 型が $3.2 \%, \mathrm{X}$ 型が $1.6 \%$ あった。

Table 1. The freguencies of phenotypes of hemoglobin in Hokkaido-native horse

\begin{tabular}{cc}
\hline Type & Freguency \\
\hline AA & $0.698(44)$ \\
Aa & $0.254(16)$ \\
a a & $0.032(2)$ \\
X & $0.016(1)$ \\
\hline ( ) : No. of animal
\end{tabular}

なお、本調査において用いた資料は日本大学農獣医学部の佐久間勇次教授より分与されたものであ る。

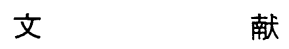

Braend, M. and C. Stormont, 1964 Nord. Vet.Med., 16:31-37.

Gahne, B., 1966 Genetics, 53:681-694.

細田達雄, 1977 畜研, 31：489-493.

Schleger, W. and P.Soos, 1968 Proc. XIth Europ. Conf. Anim.

Blood Grps. Biochem. Polymorph. (Warsaw), 447-480. 